\title{
Parapentaneura bentogomensis Stur, Fittkau et Serrano (Diptera, Chironomidae, Tanypodinae) taken in Southeastern, Brazil: additional characters and modified generic diagnosis
}

\author{
Caroline Silva Neubern de Oliveira ${ }^{1,3}$, Alaíde Aparecida Fonseca-Gessner ${ }^{2}$ \& Mário Antônio Navarro-Silva \\ ${ }^{1}$ Programa de Pós-graduação em Entomologia, Universidade Federal do Paraná - UFPR, \\ CP 19020, CEP 81531-980, Curitiba,PR, Brasil, e-mail: cneubern@yahoo.com.br, mnavarro@ufpr.br \\ ${ }^{2}$ Departamento de Hidrobiologia, Universidade Federal de São Carlos - UFSCar, \\ CP 676, CEP 13565-905, São Carlos, SP, Brasil \\ ${ }^{3}$ Corresponding author: Caroline Silva Neubern de Oliveira, e-mail: cneubern@yahoo.com.br
}

NEUBERN, C.S.O., FONSECA-GESSNER, A.A., \& NAVARRO-SILVA, M.A. Parapentaneura bentogomensis Stur, Fittkau et Serrano (Diptera, Chironomidae, Tanypodinae) taken in Southeastern, Brazil: additional characters and modified generic diagnosis. Biota Neotrop. 10(2): http://www.biotaneotropica.org.br/v10n2/ en/abstract?article+bn03710022010.

\begin{abstract}
The genus Parapentaneura was established in 2006 and is composed of a single species, Parapentaneura bentogomensis, originally from Mato Grosso State. This species was collected in São Paulo State and is thus redescribed. The specimens from both localities were compared, adding new characters to the description of the species and emending the genus diagnosis. The new record increases considerably the geographical distribution of Parapentaneura.
\end{abstract}

Keywords: new record, non-biting midges, redescription, species, taxonomy.

NEUBERN, C.S.O., FONSECA-GESSNER, A.A., \& NAVARRO-SILVA, M.A. Parapentaneura bentogomensis Stur, Fittkau et Serrano (Diptera, Chironomidae, Tanypodinae) da região Sudeste do Brasil: caracteres adicionais e diagnose genérica modificada. Biota Neotrop. 10(2): http://www.biotaneotropica.org.br/v10n2/ pt/abstract?article+bn03710022010.

Resumo: O gênero Parapentaneura foi estabelecido em 2006 e apresenta somente uma espécie, Parapentaneura bentogomensis, proveniente do Estado do Mato Grosso. Esta espécie foi coletada no Estado de São Paulo e então redescrita detalhadamente, apresentando caracteres adicionais. Os espécimes de ambas as localidades foram comparados, possibilitando o aperfeiçoamento da diagnose do gênero. O novo registro amplia consideravelmente a distribuição geográfica de Parapentaneura.

Palavras-chave: novo registro, quironomídeo, redescrição, espécie, taxonomia. 


\section{Introduction}

The genus Parapentaneura Stur, Fittkau et Serrano was established in 2006, originally described from Mato Grosso State, Brazil. This genus is similar to Pentaneura (Philippi, 1865) and Hudsonimyia (Roback, 1979) with respect to the lyrate tibial spurs and the rather short and robust hypopygium (Stur et al., 2006). The pupal stage of Parapentaneura resembles that of Larsia due characters of thoracic horn. The larval stage resembles that of Pentaneura due to the presence of the dark supraanal setae, which are longer and stronger than the anal setae and mounted on small humps (Stur et al., 2006).

The genus includes a single species, Parapentaneura bentogomensis and can be diagnosed by the following characters: imagines with lyrate tibial spurs; $\mathrm{R}_{2}$ branch absent; $\mathrm{R}_{2+3}$ connecting with Costa; anal point simple; scutal tubercle absent; comb of hind tibia distinct, with 5-6 setae, with a single spur. Pupa with alveolar horn, atrium filling most of lumen, thoracic comb consisting of 6-8 rounded tubercles and anal lobe 1.6 (female) or 1.8 (male) times longer than wide. Larval paraligula with 3 teeth, pecten hypopharyngis with 10-11 teeth, AR about 4 (Stur et al. 2006).

The record of Parapentaneura from São Paulo State extends the known range of the species considerably. The examination of the type material allows us to securely identify the additional material as belonging to this species, improving the species and genus descriptions.

\section{Material and Methods}

The material examined was mounted on slides, in Euparal, following the procedures outlined by Pinder (1983, 1986, 1989). The general terminology follows Saether (1980), Roback (1985), Kowalyk (1985), Langton (1994) and Oliver \& Dillon (1989). Unless otherwise indicated, measurements are given in $\mu \mathrm{m}$ and are given as ranges followed by the mean when more than three specimens have been measured. All the larvae were measured in the fourth instar exuviae. The coloration concerns slide mounted specimens.

The paratypes are housed in the entomological collection of Instituto Oswaldo Cruz, Rio de Janeiro, Brazil. The additional material examined is housed in the Laboratório de Entomologia Aquática of the Universidade Federal de São Carlos - UFSCar, São Paulo, Brazil and in the collection "Pe. Jesus Santiago Moure", Departamento de Zoologia, Universidade Federal do Paraná - UFPR, Paraná, Brazil.

\section{Results}

\section{Parapentaneura Stur, Fittkau et Serrano}

Generic Diagnosis. Male: wing length 1.1-1.4 mm. Antenna with 13 flagellomeres, apical flagellomere indistinctly offset, AR 1.1-1.3. Eyes with dorsomedian extension; temporals uniserial. Antepronotal lobes separated medially; scutal tubercle absent; lateral antepronotal, anepisternal, preepisternal and postnotal setae absent. Wing unmarked; membrane evenly covered with pale macrotrichia; Costa ending between $\mathrm{M}_{1+2}$ and $\mathrm{M}_{3+4} ; \mathrm{R}_{2+3}$ reaching Costa; $\mathrm{R}_{2}$ branch absent; anal lobe well developed. Fore and hind tibiae with single spur; mid tibia with two spurs; all tibial spurs lyrate, with 3-4 teeth; pulvilli absent. Tergite IX with strong posterior setae. Phallapodeme and lateral sternapodeme with characteristic shape. Gonocoxite robust, 1.5 times longer than wide, inner margin slightly concave; dorsal surface with longer marginal setae and field of short bristles medially. Gonostylus simple, short, about half the length of gonocoxite, HR 1.54-1.65. Pupa: Exuviae coloration brownish with a dark brown spots. Thoracic horn flattened, elongated; alveolar horn atrium with central duct, connected to large plastron plate by narrow neck; corona present, more than half the length of horn; thoracic comb well developed, consisting of rounded tubercles, longest tubercle more than twice as long as wide; additional small rounded projections near base of horn; anterior median surface of thorax wrinkled. Scar on tergite I elongated, pigmented. Tergite I with one prominence on each side of scar and without shagreen. Tergites with short spinules partially serially arranged in groups of 2 and 3; abdominal D setae all filamentous, robust, apically round; segment VII with 3 LS seta, shorter than length of segment; segment VIII with 5 LS setae. Anal lobe about 2 times longer than wide; outer margin sclerotized and with spinules beyond distal macroseta; remaining part hyaline, with shagreen basally; anal macrosetae with adhesive sheaths, proximal macrosetae dorsal; male genital sac about one-third the length of the anal lobe. Larva: head capsule 430-600 long; AR 3.68-4.22; ring organ near middle of basal segment. Ring organ in distal half of basal maxillary palp segment; mandible slender, basal tooth distinct; ligula with 5 subequal teeth, row of teeth straight to slightly convex, inner teeth with apices turned outwards; paraligula bi - or trifid, third tooth on inner side varying in size; pecten hypopharyngis with 6-11 teeth; S5, DP and S8 in row, slightly posteriorly directed; S7 anterolateral to S8; S9 anterior to VP; S10 posterior to VP. Anal tubules slender; supraanal setae on small tubercles with transversal grooves, stronger and longer than anal setae; posterior parapods with spinules in the extremity; claws of posterior parapods simple or with inner teeth.

Parapentaneura bentogomensis Stur, Fittkau et Serrano, 2006: 59

(Figures 1-13)

Material Examined : Paratypes, 2 males with pupal exuviae, Brazil, Mato Grosso, Bento Gomes river near Poconé, $15^{\circ} 54^{\prime} \mathrm{S}$ and 56 33' W, 14.x.1993, Serrano M. A. leg. 7 males with larval and pupal exuviae Brazil, São Paulo, São Carlos, UFSCar, Mayaca pond, $21^{\circ} 58^{\prime} 02 ., 1^{\prime \prime} \mathrm{S}$ and $47^{\circ} 33^{\prime}$ 01.,7' W, 13.ix.2004, Oliveira C.S.N. leg.

Male Imago ( $\mathrm{n}=7$; Figures $1-5)$

Total length 2.63-2.66, $2.65 \mathrm{~mm}$. Wing length 1.28-1.46, $1.37 \mathrm{~mm}$. Total length/wing length 1.82-2.05, 1.94. Wing length/ length of profemur 2.06-2.21, 2.14.

Coloration: Head, pedicel, antenna and thorax brownish. Wings with membrane evenly covered with pale macrotrichia. Legs brownish. Abdomen brownish.

Head: AR 1.12-1.28, 1.18. Apical flagellomere 50-55, 53 long. Dorsomedial extension with 3-4 facets. Temporal setae 8-9, two coronal setae. Clypeus with 8-13 setae, 80-83.7, 81 long and 63.7-70.0, 67.9 wide at largest part. Labium with one seta. Ocular ratio 1.2-1.6, 1.4. Tentorium 145 long and stipes not measurable. Cibarial pump with anterior margin weakly concave 170.0-197.5, 180.8 long. Palpomere lengths 27.5-30.0, 29.2; 43.7-55, 48.7; 75-87.5, 80.0; 93.7-105, 99.5; and 137.5-160.0, 150.4. Palpomere 2 with sensilla capitata 18.7-25, 20.8 distant of base.

Wing (Figure 1): VR 0.95. Brachiolum with three setae. Costa 1-1.3, $1.2 \mathrm{~mm}$. Sc 0.66-0.70, $0.68 \mathrm{~mm}$. $\mathrm{R}_{1} 0.3-0.45,0.37 \mathrm{~mm}$. $\mathrm{R}_{2}$ branch absent. $\mathrm{R}_{2+3} 0.41-0.53,0.46 \mathrm{~mm}$. $\mathrm{R}_{4+5} 0.69-0.78,0.73 \mathrm{~mm}$. $\mathrm{RM} 0.39-0.46,0.42 \mathrm{~mm}$ from arculus and $\mathrm{MCu} 0.37-0.44$, $0.40 \mathrm{~mm}$ from arculus. Squama with 7-13 setae. Crossvein ratio 0.67-1.0, 0.9. Cubital ratio 49.3-61, 5.0.

Legs (Figures 2-4): Leg I - width at apex of tibia 37.5-38.7, 38.1, tibia with one apical spur (Figure 2) 17.5-18.7, 17.9 long of four teeth. Apex of tibia with four preapical setae 87.5-13.0, 

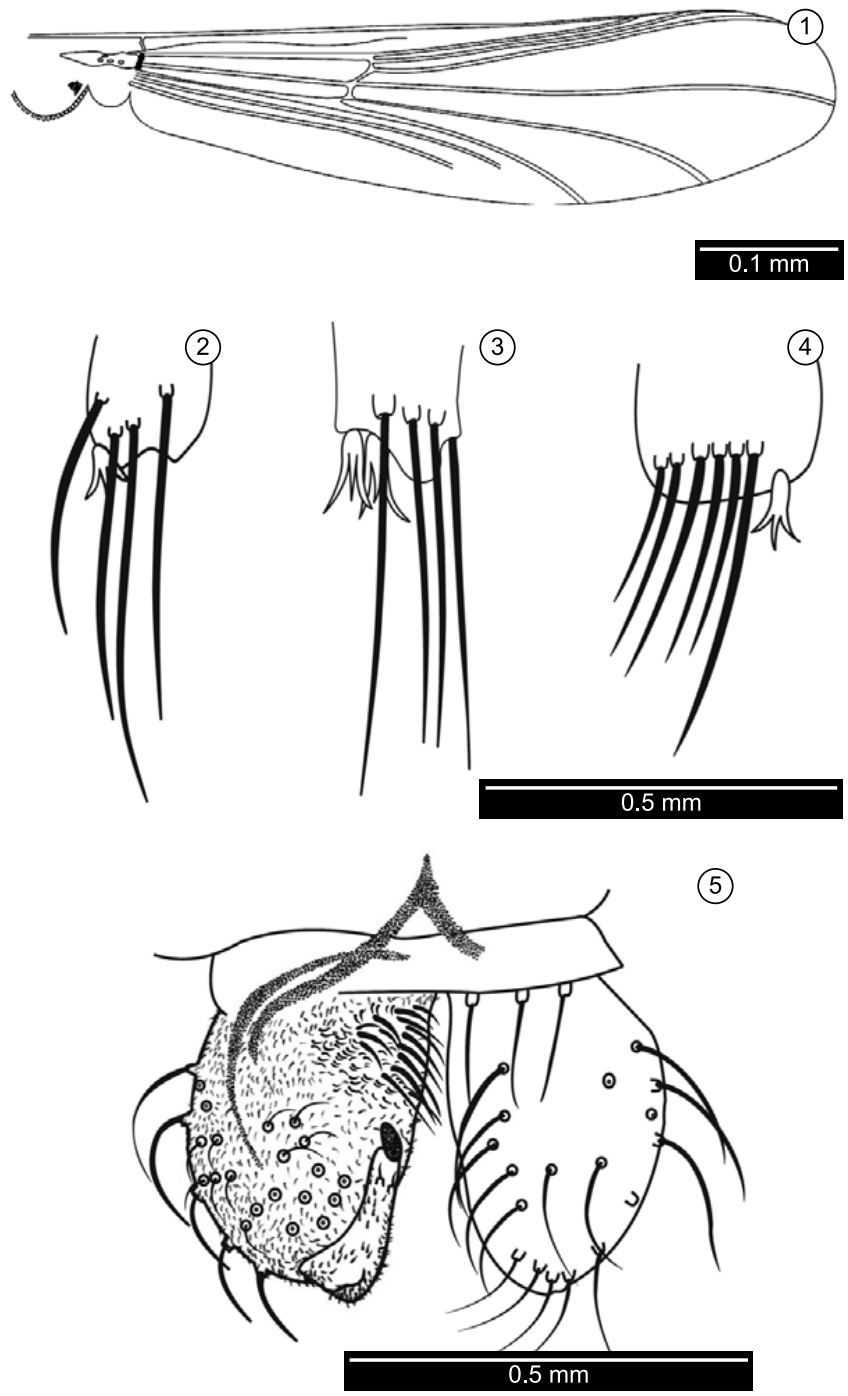

Figures 1-5. Parapentaneura bentogomensis, imagines - $\delta$ : 1 . wing; 2. apex of fore tibia; 3. apex of mid tibia; 4. apex of hind tibia; 5. tergite IX and hypopygium, left side dorsal view and right side ventral view. Scale: Figure $1=0.1 \mathrm{~mm}$ and Figures $2-5=0.5 \mathrm{~mm}$.

106.6 long. Claw 21.2 long. Leg II - width at apex of tibia 32.5-33.7, 32.9, tibia with two apical trifid spur (Figure 3) 15.0-17.5, 15.8; 17.5 long. Apex of tibia with four preapical setae 85.0-120.0, 102.5 long. Claw 21.0 long. Leg III - width at apex of tibia 42.5-50.0, 46.6, tibia with one apical trifid spur (Figure 4) 17.0-20.0, 18.2 long. Apex of tibia with comb of six setae, the first right setae bigger than others setae. Claw 21.0 long. BV 2.45-2.6, 2.5.

Hypopygium (Figure 5): Phallapodeme 75.0-81.0, 78.1 and lateral sternapodeme 75.0-80.0, 77.5 long. Gonocoxite 80.0-90.0, 85.0 long and 57.5-60.0, 59.2 wide. Gonostylus 51.2-56.2, 53.2 long, megaseta 10.0-11.0, 10.4 long. HR 1.54-1.65, 1.60, HV 4.73-5.13, 4.99.

Pupa (n = 7; Figures 6-9)

Male abdomen 2.37-2.98, $2.75 \mathrm{~mm}$. Length of thoracic horn / length of longest anal macrosetae 0.66-0.84, 0.75; length of genital sac/length of anal lobe $0.37-0.48,0.43$. Exuviae brownish with a dark brown spots (Figure 6), thoracic horn brown.
Cephalothorax: Wing sheath $0.70-0.87,0.79 \mathrm{~mm}$ long and 0.25-0.33, $0.29 \mathrm{~mm}$ width. Thoracic horn (Figure 7) 182.0-200.0, 189.0 long, maximum width 70.0-82.0, 75.6, branched or simple respiratory atrium, plastron plate 40.0-43.7, 42.0 long, wavy surface plastron plate, corona 60.0-100.0, 75.8 long, surface of thoracic horn with spines. Basal lobe next to with 8 protuberances. Thoracic comb with seven well development rounded teeth.

Abdomen (Figures 6, 8, 9): AI without shagreen, AII-VII with shagreen as in figure 8 , tergite I with scar 120.0-133.7, 127.0 long and with one prominence on each side of scar. AVII with 3 taeniae, $\mathrm{LS}_{1}$ 112.5-127.5, 120.0. AVIII with 5 taeniae, $\mathrm{LS}_{1}$ 50.0-67.5. Anal lobe (Figure 9) 350.0-375.0, 360.0 long, with 2 anal macrosetae 237.5-275.0, 256.2 long, LS $_{1}$ anal macroseta 80.0-92.0, 86.5, LS $_{2}$ anal macroseta 137.5-152.5, 144.6, medially membranous and with spinules beyond distal macroseta in the outer margins. Genital sac smaller than anal lobe, with 140-171.2, 152.9 long.

Larva ( $\mathrm{n}=7$; Figures 10-13)

Head capsule (Figures 10, 11): Length 430.0-445.0, 435.0; width 240.0-290.0, 261.6. A 225.0-237.5, 230.8 long, ring organ 117.5-130, 125 from the base, $A_{2} 50-52.5,51.6 \mu \mathrm{m}$ long. AR 3.6-4.2, 3.8. Maxillary palp with one segment, P1 32.5-36.2, 34.5 long, 8.7-10.0, 9.0 wide. $\mathrm{A}_{1} / \mathrm{P}_{1}$ 6.4-7.0, 6.7. Mandible (Figure 10) length 62.5-65.0, 63.3, with 3 lateroventral setae and 1 sensilium campaniforme, basal tooth 18.7-22.5, 20.0 from apex of mandible and with seta subdentalis 12.5 long, $\mathrm{A}_{1} / \mathrm{MD} 3.5-3.8$, 3.6. Dorsomentum with three teeth on each side distant 33.0-35.0, 34.0. Ligula (Figure 11) 53.7-55.0, 54.5 long and maximum width 30.0-31.2, with 5 teeth, It/O 1.0, Mt/O 0.7, It/Li 0.1, muscle attachment 8.7-11.2 long, trifid paraligula 27.5-31.2, 30.0 long, pecten hypopharyngis with 11 sharp teeth.

Body (Figures 12, 13): Abdomen with several setae. Procerci 155.0-162.5, 158.8 long, 16.2-20.0, 17.5 wide, with seven anal setae and one simple lateral seta, L/W 7.7-10,9. Supraanal seta (Figure 12) on small tubercles, 420.0-470.0, 450.0 long and with transversal grooves, length of supraanal seta/length of the longest anal seta 1 . Anal tubules slender, smaller than parapods. Posterior parapods with hooklets in the extremity, five claws with fine inner teeth (Figure 13).

\section{Discussion}

The Southeastern specimens falls well within the species description given by Stur et al. (2006), with the following exceptions: male, AR 1.12-1.28; wing length 1.28-1.46 mm and BV of hind leg 2.45-2.63; pupa, wavy plastron plate and branched or simple respiratory atrium; larva, head capsule length 430.0-445.0; AR 3.6-4.2; supraanal seta with transversal grooves; anal tubules slender, smaller than parapods; posterior parapods with spinules in the extremity and claws with fine inner teeth.

The comparison among the materials allowed to include some characters in the generic diagnosis: male, fore and hind tibia with single spur; mid tibia with two spurs; phallapodeme and lateral sternapodeme with characteristic shape; pupa, coloration brownish with a dark brown spots; tergite I with one prominence on each side of scar and without shagreen; larva, anal tubules slender; supraanal setae on small tubercles with transversal grooves, stronger and longer than anal setae; posterior parapods with spinules in the extremity; claws of posterior parapods simple or with inner teeth.

The larvae were collected in a small pond on the Universidade Federal de São Carlos campus, São Paulo State, Brazil. The pond`s maximum depth is $1.30 \mathrm{~m}$ and the larvae were found associated with the aquatic macrophyte Mayaca. 


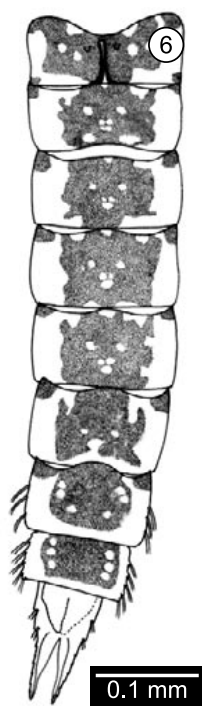

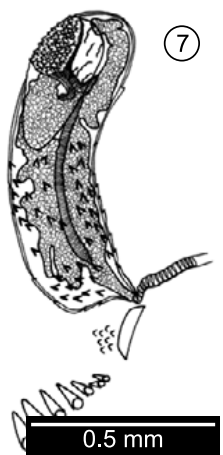
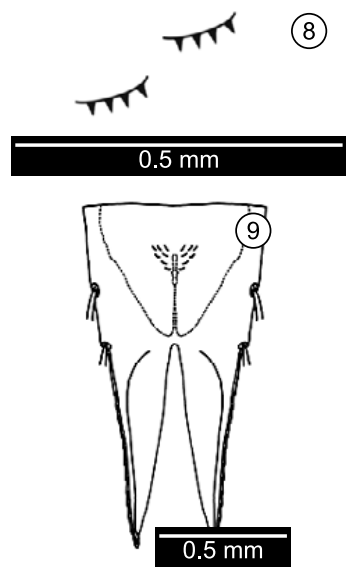

$0.1 \mathrm{~mm}$
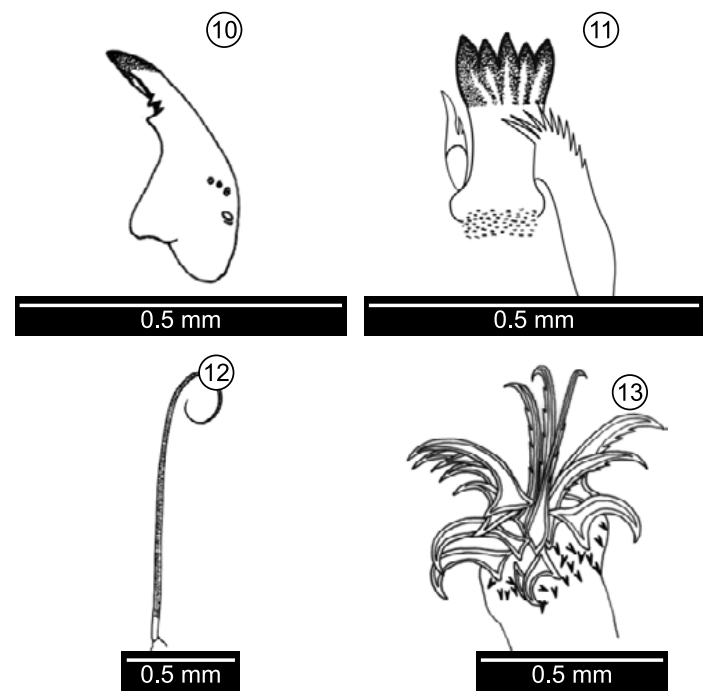

Figures 6-13. Parapentaneura bentogomensis, immatures: 6) abdominal tergites; 7) thoracic horn; 8. shagreen of segments II-IX; 9. anal lobe and genital sac, dorsal view; 10. mandible; 11. ligula, paraligula and pecten hypopharyngis; 12 . supraanal seta; 13 . apical claws of posterior parapods. Scale: Figure $6=0.1 \mathrm{~mm}$ and Figures $7-13=0.5 \mathrm{~mm}$.

\section{Acknowledgements}

We are indebted to Dr. Elisabeth Stur for explanation of some characters and also to the Fundação do Instituto Oswaldo Cruz, Fiocruz, Rio de Janeiro, Brazil, for the loan of the paratypes, and anonymous reviewer for valuable comments on the manuscript. The first author received grants from CNPq (140179/2007-0). Thanks are also due to the Programa de Pós Graduação em Entomologia da Universidade Federal do Paraná - UFPR, Brazil.

\section{References}

KOWALYK, H.E. 1985. The larval cephalic setae in the Tanypodinae (Diptera: Chironomidae) and their importance in generic determinations. Can. Ent. 117:67-106.

LANGTON, P.H. 1994. If not "filaments" then what? Chironomus 6:9.

OLIVER, D.R. \& DILLON, M.E. 1989. The adult of Chironomidae (Diptera) of the Holartic region - Introduction. In Chironomidae of the Holartic region: keys and diagnoses. Part 3: Adults Male (T. Wiederholm, ed.). Entomol. Scand. Suppl. 34:10-15.

PHILIPPI, R.A. 1865. Aufzahlung der chilenischen Dipteren. Verh. Zool.-bot. Ges. Wien, 15:595-782.
PINDER, L.C.V. 1983. The larvae of Chironomidae (Diptera) of the Holartic region - Introduction. In Chironomidae of the Holartic region: keys and diagnoses. Part 1: Larvae. (T. Wiederholm, ed.). Entomol. Scand. Suppl. 19:1-457.

PINDER, L.C.V. 1986. The pupae of Chironomidae (Diptera) of the Holartic region - Introduction. In Chironomidae of the Holartic region: keys and diagnoses. Part 2: Pupae. (T. Wiederholm, ed.). Entomol. Scand. Suppl. 28:1-482.

PINDER, L.C.V. 1989. The adult of Chironomidae (Diptera) of the Holartic region - Introduction. In Chironomidae of the Holartic region - Keys and diagnoses. Part 3. Adults male. (T. Wiederholm, ed.). Entomol. Scand. Suppl. 34:5-9.

ROBACK, S.S. 1979. Hudsonimyia karelena, a new genus and species of Tanypodinae, Pentaneurini. Proc. Acad. Nat. Sci. Philadelphia 131:1-8.

ROBACK, S.S. 1985. The immature chironomids of the Eastern United States VI. Pentaneurini-Genus Ablabesmyia. Proc. Acad. Nat. Sci. Philadelphia 137(2):153-212.

SAETHER, O.A. 1980. Glossary of chironomid morphology terminology (Diptera: Chironomidae). Entomol. Scand. Suppl. 14:1-51.

STUR, E., FITTKAU, E.J. \& SERRANO, M.S. 2006. Parapentaneura bentogomensis gen. n., sp. n., a new Tanypodinae (Diptera, Chironomidae) from Brazil. Zootaxa 1384:59-68. 